\title{
In Search for the Open Educator: Proposal of a Definition and a Framework to Increase Openness Adoption Among University Educators
}

Fabio Nascimbeni and Daniel Burgos

Universidad Internacional de la Rioja (UNIR)

\begin{abstract}
The paper explores the change process that university teachers need to go through in order to become fluent with Open Education approaches. Based on a literature review and a set of interviews with a number of leading experts in the field of Open Educational Resources and Open Education, the paper puts forward an original definition of Open Educator which takes into account all the components of teachers' work: learning design, teaching resources, pedagogical approaches and assessment methods- of teachers' activities. Subsequently, to help the development of teachers' openness capacity, the definition is further developed into a holistic framework for teachers, which takes into account all the dimensions of openness included in the definition and which provides teachers with selfdevelopment paths along each dimension. By working on the definition and on the framework with the interviewed experts, the paper concludes that a strong relation exists between the use of open approaches and the networking and collaboration attitude of university teachers, and that in order to overcome the technical and cultural barriers that hinder the use of open approaches in Higher Education, it is important to work on the transition phases - in terms of awareness and of capacity building - that teachers have to go through in their journey towards openness.
\end{abstract}

Keywords: open education, higher education, teachers, open design, open educational resources, open methodology

\section{Introduction: The Realised and Unmet Potential of Open Education}

Open Education has the potential to increase quality, access, and attractiveness of Higher Education, fostering "a more democratic and competitive higher education system, with the potential to improve access to education, develop and localize open educational services to suit local contexts, and enhance the integration of education into everyday lives as part of lifelong learning" (Butcher \& Hoosen, 2014, p. 9). Weller notes that openness has made it to the center of the Higher Education debate, especially thanks to the media interest raised by the Massive Open Online Courses (MOOCs) phenomenon, and that openness is starting to become the norm, especially in scholarly activities. "There is undoubtedly still a lot more that open education needs to do before it affects all aspects of practice, but the current period marks the moment when open education stopped being a peripheral, specialist interest and began to occupy a place in the mainstream of academic practice" (Weller, 2014 p. 9). Nevertheless, if we look at adoption of open approaches, the picture is controversial. On the one hand, research shows 
that OER, Open Educational Practices (OEP), Open Textbooks and MOOCs are increasingly being adopted by universities around the world (Esposito, 2013; European Commission, 2013; Grodecka \& Śliwowski, 2014), but on the other hand many observers agree that the outreach of the openness in education is still far from its potential impact (Glennie, Harley, Butcher, \& Van Wyk, 2012; Hollands \& Tirthali, 2014; Kortemeyer, 2013; Okada, Mikroyannidis, Meister, \& Little, 2012; Rohs \& Ganz, 2015). "Awareness of OER and Creative Commons is growing, but OER repositories remain relatively unused and unknown compared with the main three educational resource sites of YouTube, Khan Academy and TED” (De los Arcos, Farrow, Perryman, Pitt, \& Weller, 2014, p. 4). The situation is certainly evolving, even if we need to accept that the consideration made by Conole in 2008 is still valid today: "Arguably then there has never been a better alignment of current thinking in terms of good pedagogy - i.e. emphasising the social and situated nature of learning, rather than a focus on knowledge recall with current practices in the use of technologies - i.e. user-generated content, user-added value and aggregated network effects. Despite this, the impact of Web 2.0 on education has been less dramatic than its impact on other spheres of society - use for social purposes, supporting niche communities, collective political action, amateur journalism and social commentary" (as cited in Weller, 2012, p. 89).

\section{The Missing Bit in Open Education: Open Educators}

In the last years, a number of studies have been investigating the reasons for this slow adoption of open approaches, focusing mainly on OER but also on Open Policies and Open Educational Practices (Open Education Group, 2015), but very few research projects have focused on what we think is one of the major missing links for openness in education to get mainstreamed, which is the need to empower teachers and lecturers to embrace open approaches in their daily work. A number of observers agree with this priority. Back in 2005, in a report presented to UNESCO, Albright (2005) was already recognising the importance of the involvement of faculty members, both through top-down and bottom-up initiatives. Five years later, Pearce stated that "digital scholarship is more than just using information and communication technologies to research, teach and collaborate, but it is embracing the open values, ideology and potential of technologies born of peer-to-peer networking and wiki ways of working in order to benefit both the academy and society" (Pearce, Weller, Scanlon, \& Kinsley, 2010, p. 40). More recently, Allen and Seaman (2014) consider that "faculty are the key decision makers for OER adoption, across disciplines, in the opinion of both chief academic officers and faculty themselves," (p. 2) and Price (2015) states that transformation in education, to be sustainable, has to be owned by teachers, who are the people who have to implement it. In the well-known model by Boyer (1990), the work of teachers is conceptualized as a continuum that includes the activities of discovery, integration, application and teaching. We believe that the teaching function is the cornerstone for change to happen, as suggested by Pearce et al. (2010): "It is arguably in Boyer's (1990) fourth function, that of teaching, that we see the biggest impact of digital technologies and open approaches" (p. 40). Following a thorough analysis of all aspects of openness in education, Weller (2012) concludes along the same line: "When we consider the changes in scholarly practice, it is perhaps in teaching that we see the greatest potential for a radically different approach to emerge. The three key elements of digital, networked and open converge most significantly around the production, pedagogy and delivery of education" (p. 85). 


\section{Proposing an Holistic Definition of Open Educator}

The Open Educators Factory project ${ }^{1}$ is tackling specifically the need to explore the change process that university teachers need to go through is we want them to embrace openness in their teaching activities, becoming not only fluent with open approaches but also advocates of openness in higher education. During the first phase of the project we have run a literature review searching for definitions, conceptual frameworks, and guidelines targeting university teachers and aiming at improving their open fluency, and we have then discussed the results of this work with a number of experts in the field of open education, namely, Wayne Mackintosh from the OER Foundation, Rory Mc Greal from Athabasca University, UNESCO/Commonwealth of Learning/ICDE Chair in OER, Chrissi Nerantzi from Manchester Metropolitan University, Antonio Teixeira, President of the European Distance and eLearning Network, and Martin Weller from The Open University UK, ICDE Chair in OER. Given the exploratory nature of the study, we adopted a qualitative approach to data collection and analysis, by using semi-structured interviews divided into two parts: first, a traditional interview with a sequence of themes and questions, and second, an interactive activity in which experts were invited to directly comment and improve the definition and framework presented below.

A first result of the literature review, which was confirmed by the interviewed experts, is that while definitions of OER and Open Education are abundant in policy as well as in scientific literature - even if some degree of disagreement on what openness means is still present (Bates, 2011; Deyman \& Farrow, 2013), a definition that encompasses openness within teachers' activities as a whole does not seem to exist. On the other hand, we have encountered numerous analyses of the various aspects of what an Open Educator could and should do. Existing literature seems to be focusing on the objects of Open Education, such as Open Educational Resources, and more recently, MOOCs (Allen \& Seaman, 2014; Cormier, 2008; De los Arcos et al., 2014; Kortemeyer, 2013; Rolfe, 2012; Wild, 2012), or on its practices, such as Open Pedagogy (Esposito, 2013; Murphy, 2013; Okada et al., 2012), Open Design (Cochrane \& Antonczak, 2015; Conole, 2013; Laurillard, 2012), and Open Scholarship (Pearce et al., 2010; Weller 2012). In addition, teachers are often targeted with guidelines that should facilitate their development towards the adoption of OER (Butcher, 2015; Grodecka \& Śliwowski, 2014; Kreutzer, 2014; McGill, 2012) or with competencies frameworks that should structure their professional development in general terms (Department for Business, Innovation and Skills of the UK, 2015; Higher Education Academy, 2011) and with specific reference to ICT (UNESCO 2011).

When asked to point out a general definition of Open Educators, the interviewed experts focused on specific aspects of a teachers' work, but never listed all the areas of activity for teachers. At the same time, they all agree that if we want teachers not only to accompany but rather to drive the change towards openness in education, we need to have a clear and possibly shared understanding of what we mean by an Open Educator. This would help decision makers at different institutional and policy

${ }^{1}$ The Open Educators Factory research project started in April 2015 and will end in March 2017. The project is funded by the Universidad Internacional de la Rioja (UNIR) . 
levels as well as the teacher population itself to have a clear "development target" towards which to work. To fill the gap given by the absence of an holistic definition that can represent a clear target for the transformation of teachers into open educators, we created a definition which takes into account both the objects, teaching content and tools, and the practices, learning design, pedagogical, and assessment approaches, of teachers' activities. As said before, this definition is grounded on our literature review and has been worked out in collaboration with the interviewed experts, whose specific contributions are mentioned later in the analysis of the definition.

Our definition of the Open Educator is the following:

An Open Educator choses to use open approaches, when possible and appropriate, with the aim to remove all unnecessary barriers to learning. He/she works through an open online identity and relies on online social networking to enrich and implement his/her work, understanding that collaboration bears a responsibility towards the work of others.

An Open Educator implements openness along four main activities. He/she:

1. Implements open learning design by openly sharing ideas and plans about his/her teaching activities with experts and with past and potential students, incorporating inputs, and transparently leaving a trace of the development process.

2. Uses open educational content by releasing his/her teaching resources through open licenses, by facilitating sharing of her resources through OER repositories and other means, and by adapting, assembling, and using OERs produced by others in his/her teaching.

3. Adopts open pedagogies fostering co-creation of knowledge by students through online and offline collaboration and allowing learners to contribute to public knowledge resources such as Wikipedia.

4. Implements open assessment practices such as peer and collaborative evaluation, open badges, and e-portfolios, engaging students as well as external stakeholders in learning assessment.

The definition starts with a general paragraph that contextualises the expected transformation of teachers with the existing higher education context, by stating that an Open Educator choses to use open approaches when possible and appropriate, meaning that openness should always be adopted if and when it can improve the teaching process and the learners accessibility and performance in a coherent way with the institutional context under which the educator is operating. As one of the interviewed experts put it: "In a nutshell, for an Open Educator open is default, close is exception" (Macintosh, personal communication, July 21, 2015). The paragraph provides a clear answer to the question on why an educator should opt for open approaches, that is to remove all unnecessary barriers to learning (Macintosh, personal communication, July 21, 2015): here we mean both accessrelated barriers, connected for example with the socioeconomic status of students or with students' disabilities, but also the more subtle barriers connected to learning personalization, learning styles, and preferences (Teixeira, personal communication, October 7 , 2015). Then, it is specified that, as Weller suggested during the interview, an Open Educator should work through an open online identity, meaning that he/she should adopt a transparent and consistent attitude in online spaces related to his/her teaching work (Ross, Sinclair, Knox, Bayne, \& Macleod, 2014), and rely on online 
social networking to enrich and implement her teaching, making the connection clear between being open and being networked (Weller, personal communication, June 11, 2015). Finally, the definition stresses the importance of understanding the responsibility towards the work of others that comes with the adoption of open approaches, meaning that an open educator should be cautious about issues like privacy or use of personal data (Nerantzi, personal communication, October 30, 2015).

In its second part, the definition suggests that openness should pervade all the components of teachers' work: the way a teacher designs his/her courses, the way he/she licenses, creates, and shares learning content, the pedagogical practices, and the assessment approaches implemented. The definition is based on the assumption that a correct process of "opening up education," to use the wording of a recent initiative by the European Commission (European Commission, 2013), should be based on opening up all these four components (design, content, teaching, and assessment) that ideally "shall coexist and complement each other within a generalised open culture" (Nerantzi, personal communication, October 30, 2015). First, opening up learning design, by co-designing curriculum and courses with peers and students and allowing the courses to evolve and improve year after year, as "a creative way to breath new life and fresh ideas into course design" (Cochrane \& Antonczak, 2015, p. 3). Second, opening up the teaching content, by releasing course material as Open Educational Resources and by making sure it is findable and usable by others (McGreal, personal communication, November 30, 2015). Third, adopting open pedagogical approaches, intended as "a blend of strategies, technologies, and networked communities that make the process and products of education more transparent, understandable, and available to all the people involved" (Grush, 2014, para. 4). Fourth, implementing open assessment practices such as peer evaluation or e-portfolios, opening up the assessment also to the courses themselves, so as to improve them based on peer and student feedback (Nerantzi, personal communication, October 30, 2015) Further, opening up education means also to open up the organisational and learning boundaries of one's teaching activities, for example allowing students to follow courses in an open MOOC style also if they are not enrolled in the university (Dalsgaard \& Thestrup, 2015; Weller, personal communication, June 11, 2015), or working towards the provision solutions towards accreditation of the knowledge acquired (Macintosh, personal communication, July 21, 2015; Peterson, 2014).

All interviewed experts pointed out that the transition of teachers towards openness must be seen in a broader change process, connected both with the actual crisis of university systems (High Level Group on the Modernisation of Higher Education, 2013; Sledge \& Dovey Fishman, 2014) and with the possibilities offered by ICT and social media. University teachers have always considered themselves as the experts in the body of knowledge that needs to be communicates to students for them to get educated. This role is being increasingly questioned by educational researchers, who claim that thanks to the spread of ICT and to the open and networked approached that they have made possible, new forms of social learning are emerging that challenge the traditional roles within education systems, and in particular the idea that teachers are the only ones entitled to produce knowledge (Schmidt, Geith, Håklev, \& Thierstein, 2009). "Since the distributed and networked structure of knowledge in the digital age challenges the traditional view of education delivered within the borders of school, strict time periods, and content, the role of the teacher has been redefined in the context of the connectivist paradigm to include networked learning environments" (Ozturk, 2015, p. 6). In a nutshell, teachers should become critical friends, co-travelers, mediators, and facilitators (Anderson \& Dron, 2011; Bates, 2015; Downes, 2012; McLoughling \& Lee, 2008; Rivoltella \& Rossi, 2012). Notably, this change should not be limited only to staff with a teaching function within universities, but applies 
also to other stakeholders involved in the learning process, such as curriculum designers, learning material designers, librarians, assessors and validators of learning, teacher trainers, pedagogical advisors and consultants, support staff, quality assurance professionals (Teixeira, personal communication, October 7, 2015).

\section{Open Teaching, Beyond OER, and OEP}

The few existing definitions of Open Educator - probably because they were developed when content and courseware were at the center of the open education debate - are built around the idea that an open teacher is the one that uses OER. For example, in 2009, Wiley and Hilton defined open educators as the ones who "publish their course materials online under an open license before the beginning of the course and invite students from outside their university to participate in the course together with the official students of the course" (p. 11). Even if this definition contains a fundamental element of openness that is the importance of opening up courses to non-enrolled students, we believe that adopting OER is just the first necessary step for educators to get open, and that other elements should be present in a definition of Open Educator, starting from the adoption of open teaching (McGreal, personal communication, November 3, 2015).

Building on and adapting the work of McLoughlin and Lee (2008), Stacey (2013), and Reynolds (2015) we propose some reflections on what we mean with open teaching with the aim to show that an Open Educator today should be conceptualized in a much broader way with respect to a teacher who uses openly released resources. First, considering that learners today have a much easier and fact access to ideas, resources, and environments that supports their learning interests and choices, open teaching means to engage the learner in the social process of knowledge development instead of just letting them use the information and learning material presented by the teacher. Second, open teaching means to consider learners as individuals and independent agents within the learning process, allowing them to operate independently and learn at their own pace, in their own direction, and using their own connections. Third, open teaching means to consider your classroom as a learning network, where each connection represents a possibility for learning, using peer-to-peer pedagogies and group assignments over self-study and classroom-based didactic learning pedagogies. Fourth, open teaching means to focus learning design on the learning process rather than on specific outcomes or competencies, since this will empower learners to think in terms of problems and solutions and will provide the possibility to inspire new perspectives and ideas. Fifth, within open teaching, learners should be encouraged to make learning choices and allowed to make mistakes, since choosing often leads to unexpected and unpredictable results, and while there is risk associated with the unknown, there is even greater reward and goodness. Finally, as stressed during the interviews by a couple of experts, within open teaching educators must support connections, dialogues and links within and across learning communities for the purpose of sharing ideas and to solve problems (McGreal, personal communication, November 3, 2015). In summary, open teaching means taking full advantage of the possibilities offered by the web, through an increased degree of socialization and interactivity, access to open environments, and opportunities for easier use of peers. As Teixeira put it during our interview, "good open teaching is the one that can transform access to good OER through organised OEP into meaningful learning” (Teixeira, personal communication, October 7, 2015). 
Open teaching methods should not be confused with Open Educational Practices (OEP), since in our understanding, open teaching can take place even without the use of OER, while typically OEPs are defined as a further step of the openness journey that follows and enriches the use of OER. OEPs have been defined as the "usage of open educational resources in the frame of open learning architectures" (Camilleri \& Ehlers, 2011, p. 6), as "practices which support the creation, use and management of OERs through institutional policies, promote innovative pedagogical models, and respect and empower learners as co-producers on their lifelong learning path" (Andrade et al., 2011, p. 12), or as "the formal assessment and accreditation of informal learning undertaken using OERs" (Murphy, 2013, p. 2). The OPAL consortium (2011) appropriately states that OEP foster the incorporation of social learning in the learning environment, but then again connects the use of open methods to OER: "The social learning element is coming in because learners can use educational resources, modify them and present them to other learners (...), knowledge environments on the basis of OER can be created by learners and shared with other learners or teachers" (p. 3). We believe it is important to "disconnect" the concept of open teaching from the use of OER since many teachers are indeed using open methodologies in their classroom activities, for example by fostering co-creation of knowledge from students allowing them to enrich the course content with any complementary information they deem important. In our view, these teachers can be indeed considered Open Educators even if they do not use - and maybe do not even know the existence of - OER. Instead of focusing on OER as the necessary first step of openness, the Open Educator definition proposed above provides a number of entry points into openness (learning design, content, methods, and research) since this would motivate a teacher that is already used to think openly in one of these areas of activity to explore and adopt open approaches in the other areas.

\section{A Self-Development Framework to Foster Openness for Educators}

In order to help the development of teachers' openness capacity, we are proposing a self-assessment and development framework for teachers that takes into account all the dimensions of openness included in the definition previously presented. The framework, presented in Table 1 below, has been discussed in detail during our interviews, and has been enriched in its structure and definition by the contacted experts. In the columns we represent the four areas of activity of our open educator definition (design, content, teaching and assessment), while in the rows we have categorised - with a necessary degree of generalisation - the different typologies of educators with respect to openness for each area of activity. To make an example, in the teaching area (third column of our table), the three layers correspond to the three predominant learning spaces in higher education as identified by Cronin: "physical classrooms (e.g., lecture halls, classrooms, labs), bounded online spaces (e.g., members-only Learning Management Systems or online communities), and open online spaces (e.g., the web, open platforms, social media, etc.)" (Cronin, 2014, p. 2).

Table 1

The Open Educators Factory Framework

Areas of Activity

\begin{tabular}{|l|l|l|l|}
\hline A. Design & B. Content & C. Teaching & C. Assessment \\
\hline
\end{tabular}




\begin{tabular}{|c|c|c|c|c|}
\hline \multirow{3}{*}{$\begin{array}{l}\text { Layer three: Open } \\
\text { collaboration }\end{array}$} & & & & \\
\hline & Open designer & OER expert & Open teacher & Open evaluator \\
\hline & \multicolumn{4}{|c|}{ Second transition phase: Transformation into Open Educator } \\
\hline \multirow{2}{*}{$\begin{array}{l}\text { Layer two } \\
\text { Bilateral } \\
\text { collaboration/ } \\
\text { Small groups }\end{array}$} & $\begin{array}{c}\text { Collaborative } \\
\text { designer }\end{array}$ & OER novice & $\begin{array}{l}\text { Engaging } \\
\text { teacher }\end{array}$ & $\begin{array}{c}\text { Innovative } \\
\text { evaluator }\end{array}$ \\
\hline & \multicolumn{4}{|c|}{ First transition phase: Awareness } \\
\hline $\begin{array}{l}\text { yer one: } \\
\text { lividual work }\end{array}$ & $\begin{array}{l}\text { Individual } \\
\text { designer }\end{array}$ & OER-null & $\begin{array}{l}\text { Traditional } \\
\text { teacher }\end{array}$ & Lone evaluator \\
\hline
\end{tabular}

Starting from the bottom, for each column we have defined three levels of openness that an educator reaches once she goes through some necessary transition phases that are transversal to all four components. The first transition phase has to do with being aware of open approaches and today continues to represent the main obstacle for teaching populations to opt for openness (Browne, Holding, Howell, \& Rodway-Dyer, 2010; Nerantzi, personal communication, October 30, 2015, Weller, personal communication, June 11, 2015). The second transition phase deals with becoming fluent with openness: once gone through this transition, an educator should be able to adopt open approaches as default in the way she designs her courses, she develops and shares content, she interacts with students, and she carries on learning assessment.

The framework shows that for all areas of activity a clear correspondence exists between the level of openness of an educator - conceptualised in the three horizontal layers in the table - and her collaboration and networking attitudes. This relation between open approaches and open networking was often stressed during the interviews: "An Open Educator is by nature a networked educator" (Weller, personal communication, June 11, 2015). The educators typologies at the bottom of the table individual designers, OER-null educators, traditional teachers, and lone evaluators - all have in common the fact that they do not rely systematically on collaboration in their daily work; specifically, they do not share with others their courses ideas, they do not openly release their teaching materials nor use materials produced by others, and they do not engage students in cooperation activities nor in assessment. One layer up, the collaborative designers, the OER novices, the engaging teachers, and the innovative evaluators all have in common the fact that they typically collaborate bilaterally or though small-group collaboration with peers and colleagues, either from the same university or through online means: "All teachers collaborate with colleagues next door, the challenge is to collaborate openly with peers you have never met in person" (Macintosh, personal communication, July 21, 2015). Finally, educators in the third layer are the ones that adopt open online collaboration practices in the way they design their courses, release their materials and reuse materials by others, and in the way they teach and assess students. As suggested by Weller during the interview, at this level of openness fluency, teachers typically rely on an open online identity and make full and confident use of online communities and social networks (personal communication, June 11, 2015). The relation between openness and networking is in line with the findings of a number of researchers in the field (Esposito, 2013; Murphy, 2013; Okada et al., 2012; Orr, Rimini, \& Van Damme, 2015; Recker, Yuan, \& Ye., 2014; Weller, 2011, 2012, 2014) and was stressed by Macintosh: "Starting from connected learning is the right angle: if we start from collaborating and networking, openness will 
come. You can't be an open educator without being transparent in what you do" (personal communication, July 21, 2015). The importance of looking at networking and at stakeholders' involvement when working to improve openness adoption among the teachers' population was stressed by Teixeira during his interview: "Teachers are a key element in the process but they are not the only missing link. The missing link is an articulated holistic approach: you can have a supportive government with funding, great institutional strategy, inspiring leadership, wonderful teachers, willing families and students, but to be successful you need to have all of this together and articulated" (personal communication, October 7, 2015).

It is important to notice that typically an educator will be more open in one or more areas of work and less in others. A teacher might be releasing her content openly, falling in the category of OER-novice, and fostering collaboration among students through flipped-classroom methods bring in the innovative teacher category, but might have never experimented with open design or open assessment. On the other hand, a teacher might be adopting peer-based assessment practices but, for whatever reason, might not be releasing her content as OER. All the interviewed experts agreed that the strength of the table stands in the fact that it can spot any advancement towards openness in any single area of activity, and can therefore motivate educators to explore other areas of work where open approaches can be adopted. In other words, by using the table as a self-reflection tool, an educator will not simply understand whether she falls in the "open educator" category or not - we fear that the very great majority of educators would not qualify in the top layer in all columns, as mentioned during the interviews by most of the experts - but she will get an understanding on how she is doing across all dimensions of openness and she will be motivated to improve her openness performance in other areas.

In the expanded version of the framework in Table 2 below, which has been improved by the interviewed experts who had the possibility of questioning and commenting through a wiki platform, we are defining what the activities are that characterise an educator in each cell.

Table 2

The Open Educators Factory Framework in Details

\begin{tabular}{|c|c|c|c|}
\hline A. Design & B. Content & C. Teaching & D. Assessment \\
\hline Open designer & OER expert & Open teacher & Open evaluator \\
\hline Shares his/her course & Re-shares resources & Encourages & Uses \\
\hline design ideas and & that he/she & participation & assessment practices \\
\hline curriculum openly & reused openly & non-enrolled & such as \\
\hline through social media, & through social media & students in his/her & assessment or e- \\
\hline including with & and . OER & courses. & portfolios. \\
\hline colleagues and with & repositories. & Implements methods & Engages \\
\hline & $\begin{array}{l}\text { uses resources } \\
\text { created by others. }\end{array}$ & creation & practices to assess \\
\hline & Searches for OER & knowledge & students' work. \\
\hline & through social media & students. & \\
\hline & $\begin{array}{l}\text { and repositories. } \\
\text { Shares and promotes }\end{array}$ & $\begin{array}{l}\text { Fosters students to } \\
\text { contribute to public }\end{array}$ & \\
\hline & resources produced & knowledge resources. & \\
\hline & by his/her students. & Encourages learners & \\
\hline & Shares links and & to access & \\
\hline & resources beyond the & available & \\
\hline & classroom, through & content. & \\
\hline & an open online & Shares examples of & \\
\hline
\end{tabular}




\begin{tabular}{|c|c|c|c|}
\hline & identity. & $\begin{array}{l}\text { teaching practice in } \\
\text { open subject-related } \\
\text { communities. }\end{array}$ & \\
\hline \multicolumn{4}{|c|}{ Second transition phase: Transformation into Open Educator } \\
\hline $\begin{array}{l}\text { Collaborative } \\
\text { designer } \\
\text { Collaborates in } \\
\text { designing his/her } \\
\text { courses with close } \\
\text { colleagues, either } \\
\text { from the same } \\
\text { university or from } \\
\text { international subject- } \\
\text { related teams. }\end{array}$ & \begin{tabular}{l}
\multicolumn{3}{l}{ OER novice } \\
Re-shares resources \\
that he/she has \\
reused among close \\
colleagues. \\
Produces and share \\
his/her \\
resources under owen \\
licences. \\
Reuses resources \\
recommended by \\
trusted people.
\end{tabular} & $\begin{array}{l}\text { Engaging teacher } \\
\text { Adopts seminars-like } \\
\text { strategies, either } \\
\text { offline or through } \\
\text { restricted online } \\
\text { spaces. } \\
\text { Uses "flipped- } \\
\text { classroom" } \\
\text { methodologies. } \\
\text { Uses the university } \\
\text { LMS, to share links } \\
\text { and resources with } \\
\text { the students of her } \\
\text { courses. }\end{array}$ & $\begin{array}{l}\text { Innovative } \\
\text { evaluator } \\
\text { Experiments } \\
\text { peers-based } \\
\text { assessments } \\
\text { methods. }\end{array}$ \\
\hline \multicolumn{4}{|c|}{ First transition phase: Awareness about openness } \\
\hline $\begin{array}{l}\text { Individual } \\
\text { designer } \\
\text { Designs his/her } \\
\text { courses on his/her } \\
\text { own, based on } \\
\text { previous knowledge } \\
\text { and experience. }\end{array}$ & $\begin{array}{l}\text { New to OER } \\
\text { Might use digital } \\
\text { resources found on } \\
\text { the web to enhance } \\
\text { teaching } \\
\text { learning. } \\
\text { Does not produce } \\
\text { openly } \\
\text { content. licensed }\end{array}$ & $\begin{array}{l}\text { Traditional } \\
\text { teacher } \\
\text { Adopts traditional } \\
\text { trasmissive pedagogy }\end{array}$ & $\begin{array}{l}\text { Traditional } \\
\text { evaluator } \\
\text { Uses traditional } \\
\text { assessment methods } \\
\text { such as tests or } \\
\text { classwork. }\end{array}$ \\
\hline
\end{tabular}

\section{Analysis: The Importance of Transition Phases}

The definition and the framework presented above are based on the assumption that all areas of an educator activity could and should be improved by adopting open approaches. On the other hand, all the interviewed experts agreed that changing the way educators plan their courses, license their materials, support knowledge creation among students, and evaluate learners' progress means changing all aspects of their professional activities, and is therefore an extremely difficult and delicate process. The introduction of technology within an educator's work is already problematic, mainly because, as suggested by Bates, most educators in higher education have never been trained to teach (Bates, 2015). If this learning by doing approach works for traditional teaching, when we move to ICT-intensive teaching a much higher standard of pedagogic capacity for faculty and lecturers is needed: "The use of technology needs to be combined with an understanding of how students learn, how skills are developed, how knowledge is represented through different media and then processed, and how learners use different senses for learning." (Bates, 2015, p. 420). The introduction of open practices within education brings in another set of tensions which go more in depth and have to do with a major cultural shift within the educators' attitudes and self-perception, related to the need of rethinking and reshaping the roles played by teachers and students within the learning process and the underpinning knowledge production process, working in an open and transparent environment where all traditional implications of learning design, delivery, and assessment are questioned (Crook \& Harrison, 2008; Orr et al., 2015; Rivoltella \& Rossi, 2014). These cultural barriers represent the biggest obstacle for the transformation of HE professors, lecturers, and instructors into open educators. When asked to list the main barriers to an effective transformation of teachers into open educators, the interviewed experts agreed on the importance of cultural aspects, mentioning as main challenges the low recognition of open education practices from leaders and peers and the ownership- 
related fears connected to the peers-scrutiny anxiety of sharing design and educational materials. The issue of transparency was quoted several times during the interviews (Nerantzi, personal communication, October 30, 2015; Teixeira, personal communication, October 7, 2015). "The increased transparency brought by Open Education is the most dramatic change for teachers and students. For teachers because opening up their classroom to anyone means losing control of the processes going on there, and for students because knowing that everyone can watch what they do is a big problem" (Teixeira, personal communication, October 7, 2015).

These problems are further exacerbated by the generalised low level of adoption of social media in teaching settings (Jaschik \& Lederman, 2013). Among the few studies have been looking into the use of social media by educators in universities, Manca and Ranieri (2015), reporting on a 2015 survey targeting the whole HE teaching population in Italy, conclude that the great majority of respondents never use Twitter (94,5\%), Slideshare $(84,5 \%)$, or Researchgate/Academia.edu $(74,4 \%)$ for teaching purposes and that "Social Media tools are mainly perceived as a waste of time, as a great concern about privacy and as a risk to weaken the traditional roles of teacher and student" (p. 110).

These barriers are particularly dangerous when an educator has to go through the transition phases of the framework presented above. If we consider for example the transitions connected to the learning content column, these cultural barriers translate in a number of practical problems, dealing with discoverability of OER, quality control, and contextual adaptation (Kortemeyer, 2013). Here is when the institutional support should play a role (Teixeira, personal communication, October 7, 2015), by facilitating the process of openness capacity building of educators by removing institutional barriers such as the lack of time to explore and learn about OER and the low institutional and social reward systems (Arendt \& Shelton, 2009; CERI-OECD, 2007).

In order to facilitate the overcoming of these barriers, we should make sure that some clear motivating messages are delivered to educators when they are about to go through a transition phase. To overcome the first transition, which deals with awareness of openness, we would need for example to pass the message that adopting open approaches would have a positive impact on teaching practices and on learning achievements in many ways, stressing that adopting open approaches "is likely to lead to more transparency in terms of how our educational provision is designed, delivered, supported and evaluated. It should result in better sharing and discussion of learning and teaching, leading ultimately to a cultural change in practice" (Conole, 2013, p. 205). To overcome the second barrier, we should focus on the different ways through which openness can impact on educators careers and on their appreciation by peers, in terms of increased audience for their work, increased efficiency with lower cost for content production, increased students access, increased possibilities for experimentation to enhance the students' learning experience, increased reputation (McGill, 2012; Weller, 2014). At the same time, we need to make clear that openness requires work: "We need to recognise that open is harder than close if we want to reach mainstream change" (Macintosh, personal communication, July 21, 2015).

\section{Conclusions}

In order to facilitate the transition process that university teachers have to go through is we want them to embrace openness in their teaching activities, we have developed an original definition of 
Open Educator which aims to go beyond the use of OER, taking into account both the teaching resources and the teaching practices - learning design, pedagogical, and assessment approaches - of teachers' activities. We have then developed the definition into a practical framework that presents development paths for Higher Education teachers along four dimensions: learning design, teaching resources, teaching strategies, and assessment methods. By working on the definition and on the framework with a number of experts in the field, we have reached three main conclusions. First, a holistic definition of Open Educator would be useful for the Open Education policy and research community, since it would help defining a target for capacity development actions in the field. Second, a strong relation exists between the use of open approaches and the networking and collaboration attitude of university teachers, where open online identities seem to be a key to develop open teaching strategies. Third, in order to overcome the technical and cultural barriers that hinder the use of open approaches in Higher Education it is important to work on the transition phases that teachers have to go through in their journey towards openness, in terms of awareness raising as well as of capacity building. These considerations will guide the second phase of our research, which will focus on piloting the above framework among university teachers, to test its acceptance level and its relevance in the eyes of educators, and to validate the idea - proposed with the Open Educator definition and detailed with the self-development framework - that a real transformation into an Open Educator must tackle at the same time all the areas of a teachers' work, leaving time and space for learning and valorising the areas where teachers are more advanced in terms of openness and networking.

\section{References}

Albright, P. (2005, December). Final report of the internet discussion forum of the international institute for educational planning. International Institute for Educational Planning.

Retrieved from

http://www.unesco.org/iiep/virtualuniversity/media/forum/oer_forum final_report.pdf

Allen, E., \& Seaman, J. (2014). Opening the curriculum: Open educational resources in U.S. higher education. Babson Research Group. Retrieved from http://www.onlinelearningsurvey.com/reports/openingthecurriculum2014.pdf

Anderson, T., \& Dron, J. (2011). Three generations of distance education pedagogy. International Review of Research in Open and Distributed Learning, 12(3). Retrieved from http://www.irrodl.org/index.php/irrodl/article/view/89o/1826

Arendt, A. M., \& Shelton, B. E. (2009). Incentives and disincentives for the use of opencourseware. The International Review of Research in Open and Distributed Learning, 10(5). Retrieved from http://www.irrodl.org/index.php/irrodl/article/view/746/1393

Bates, T. (2011, 18 March). A reflection on the OER debate: Every which way but loose. Retrieved from http://www.tonybates.ca/2011/03/18/a-reflection-on-the-oer-debate-every-which-waybut-loose/\#sthash.W46gsMWv.dpuf

Bates, T. (2015). Teaching in the digital age. BC Open Textbooks. Retrieved from http://opentextbc.ca/teachinginadigitalage/ 
Boyer, E. L. (1990). Scholarship reconsidered: Priorities of the professoriate. Princeton, N.J: Carnegie Foundation for the Advancement of Teaching.

Browne, T., Holding R., Howell A., \& Rodway-Dyer S. (2010). The challenges of OER to academic practice. Journal of Interactive Media in Education, 1(15). Retrieved from http://jime.open.ac.uk/article/2010-3/pdf

Butcher, N. (2015). A basic guide to open educational resources. Vancouver: Commonwealth of learning.

Butcher, N., \& Hoosen, S. (2014). How openness impacts on higher education. Moscow: UNESCO Institute for Information Technologies in Education.

Camilleri, A., \& Ehlers, U. (2011). Mainstreaming open educational practices. OPAL Consortium. Retrieved from efquel.org/wp-content/uploads/2012/03/Policy_Support_OEP.pdf

CERI-OECD. (2007). Giving knowledge for free: The emergence of open educational resources. Paris: OECD.

Cochrane, T., \& Antonczak, L. (2015). Developing students' professional digital identity. 11th International Conference Mobile Learning 2015. Retrieved from http://files.eric.ed.gov/fulltext/ED562441.pdf

Conole, G. (2008). New schemas for mapping pedagogies and technologies. Ariadne, 56 . Retrieved from http://www.ariadne.ac.uk/issue56/conole

Conole, G. (2013). Designing for learning in an open world. New York: Springer.

Cormier, D. (2008, 24 November). Open educational resources: The implications for educational development. Retrieved from http://davecormier.com/edblog/2009/11/24/openeducational-resources-the-implications-for-educational-development-seda

Cronin, C. (2014, April). Networked learning and identity development in open online spaces. In S. Bayne, C. Jones, M. de Laat, T. Ryberg, \& C. Sinclair, Proceedings of the 9th International Conference on Networked Learning 2014. University of Edinburgh.

Crook, C., \& Harrison, C. (2008). Web 2.o technologies for learning at key stages 3 and 4. Coventry: BECTA.

De los Arcos, B., Farrow, R., Perryman, L.-A., Pitt, R, \& Weller, M. (2014). OER Evidence Report 2013-2014. OER Research Hub. Retrieved from http://oerresearchhub.org/2014/11/19/oerevidence-report-2013-2014

Dalsgaard, C., \& Thestrup, K. (2015). Dimensions of openness: Beyond the course as an open format in online education. International Review of Research in Open and Distance Learning, 16(6). Retrieved from http://www.irrodl.org/index.php/irrodl/article/view/2146

Department for Business, Innovation and Skills of the UK. (2015). Fulfilling our potential. Teaching Excellence, Social Mobility and Student Choice. Retrieved from 
https://www.gov.uk/government/consultations/higher-education-teaching-excellence-socialmobility-and-student-choice

Deyman, M., \& Farrow, R. (2013). Rethinking OER and their use: Open education as building. International Review of Research in Open and Distance Learning, 14(3). Retrieved http://www.irrodl.org/index.php/irrodl/article/view/1370/2542

Downes, S. (2012). Connectivism and connective knowledge: Essays on meaning and learning networks. Ottawa: National Research Council Canada. Retrieved from http://www.downes.ca/files/books/Connective Knowledge-19May2012.pdf

Esposito, A. (2013). Neither digital or open. Just researchers: Views on digital/open scholarship practices in an Italian university. First Monday, 18. Retrieved from http://firstmonday.org/ojs/index.php/fm/article/view/3881

European Commission. (2013). Communication on 'opening up education: Innovative teaching and learning for all through new technologies and open educational resources. Luxembourg: European Commission.

Glennie, J., Harley, K., Butcher, N., \& Van Wyk, T. (2012). (Eds.). Open educational resources and change in higher education: Reflections from practice. Vancouver: Commonwealth of Learning. Retrieved from http://www.col.org/PublicationDocuments/pub PS OER web.pdf

Grodecka, K. \& Śliwowski, K. (2014). OER Mythbusting. European Open Edu Policy Project. Retrieved at http://mythbusting.oerpolicy.eu/wp-content/ uploads/2014/11/OER Mythbusting.pdf

Grush, M. (2014, 12 November). Open pedagogy: Connection, community, and transparency. Campus Technology. Retrieved from http://campustechnology.com/articles/2014/11/12/open-pedagogy-connection-communityand-transparency.aspx

High Level Group on the Modernisation of Higher Education. (2013). Report to the European commission on improving the quality of teaching and learning in Europe's higher education institutions. Luxembourg: Publishing Office of the European Union, doi:10.2766/42468.

Higher Education Academy. (2011). The UK Professional Standards Framework for teaching and supporting learning in higher education. Retrieved from https://www.heacademy.ac.uk/recognition-accreditation/uk-professional-standardsframework-ukpsf

Hollands, F. M., \& Tirthali, D. (2014). MOOCs: Expectations and reality. Full report. New York: Center for Benefit-Cost Studies of Education, Columbia University.

Jaschik, S., \& Lederman, D. (2013). The 2013 inside higher ed survey of faculty attitudes on technology. Inside Higher Ed. Retrieved from https://www.insidehighered.com/news/survey/survey-faculty-attitudes-technology 
Kortemeyer, G. (2013, Nov/Dec). Ten years later: Why open educational resources have not noticeably affected higher education, and why we should care. Educause Review. Retrieved from http://www.educause.edu/ero/article/ten-years-later-why-open-educational-resources-havenot-noticeably-affected-higher-education-and-why-we-should-ca

Kreutzer. T. (2014). Open content - A practical guide to using creative commons licences. Bonn: German Commission for UNESCO.

Laurillard, D. (2012). Teaching as a design science: Building pedagogical patterns for learning and technology. New York: Routledge.

Manca S., \& Ranieri M. (2015). Social media in higher education. How Italian academic scholars are using or not using Web 2.0 tools in their personal, teaching and professional practices. In F. Falcinelli, T. Minerva, \& P. C. Rivoltella (Eds.), Apertura e flessibilità nell'istruzione superiore: oltre l'e-learning. Atti del convegno SiremSiel 2014, Perugia 13-15 Novembre 2014. Reggio Emilia, Sie-l Editore, pp. 107-112.

McGill, L. (2012). JISC open educational resources infoKit. London: JISC. Retrieved from https://openeducationalresources.pbworks.com/w/page/24836480/Home

McLoughlin, C., \& Lee, M. J. W. (2008). The 3 P's of pedagogy for the networked society: Personalization, participation, and productivity. International Journal of Teaching and Learning in Higher Education, 2O(1), 10-27. Retrieved from http://www.isetl.org/ijtlhe/articleView.cfm?id=395

Murphy, A. (2013). Open educational practices in higher education: Institutional adoption and challenges. Distance Education, 34(2).

Okada, A., Mikroyannidis, A., Meister, I. \& Little, S. (2012). "Colearning" - Collaborative open learning through OER and social media in: Open educational resources and social networks: Co-learning and professional development. London: Scholio Educational Research \& Publishing.

OPAL consortium. (2011). Discussion paper: "Open educational practice - approaching a definition for a new concept”. Essen: OPAL Consortium.

Open Education Group. (2015). The review project. Retrieved from http://openedgroup.org/review

Orr, D., Rimini, M., \& Van Damme, D. (2015). Open educational resources: A catalyst for innovation. Paris: OECD. DOI: http://dx.doi.org/10.1787/9789264247543-en

Ozturk, H. T. (2015). Examining value change in MOOCs in the scope of connectivism and open educational resources movement. International Review of Research in Open and Distributed Learning, 16(5). Retrieved from http://www.irrodl.org/index.php/irrodl/article/view/2027

Pearce, N., Weller, M., Scanlon, E., \& Kinsley, S. (2010). Digital scholarship considered: How new technologies could transform academic work. Education, 16(1). Retrieved from http://ineducation.ca/ineducation/article/view/44 
Peterson, P. (2014). Alternative ways to earn your degree: Discussing OER university with Rory McGreal. Study.com. Retrieved from http://study.com/articles/Alternative Ways To Earn Your Degree Discussing OER Uni versity with Rory McGreal.html

Price, D. (2015, April 16). What will education look like in a more open future? Mind/shift. Retrieved from http://ww2.kqed.org/mindshift/2015/04/16/what-will-education-look-like-in-a-moreopen-future

Recker, M., Yuan, M., \& Ye. L. (2014). Crowdteaching: Supporting teaching as designing in collective intelligence communities. International Review of Research in Open and Distributed Learning, 15(4). Retrieved from http://www.irrodl.org/index.php/irrodl/article/view/1785

Reynolds, R. (2015, February 24). Eight qualities of open pedagogies. Nextthought.com. Retrieved from https://nextthought.com/thoughts/2015/02/ten-qualities-of-open-pedagogy

Rivoltella, P. C., \& Rossi, P. G. (Eds.) (2012). L'agire didattico. Brescia: Editirice La Scuola.

Rohs, M., \& Ganz, M. (2015). MOOCs and the claim of education for all: A disillusion by empirical data. International Review of Research in Open and Distance Learning, 16(6). Retrieved from http://www.irrodl.org/index.php/irrodl/article/view/2033/3527

Rolfe, V. (2012). Open educational resources: Staff attitudes and awareness. Research in Learning Technology, (20), 1-13.

Ross, J., Sinclair, C., Knox, J., Bayne, S., \& Macleod, H. (2014). Teacher experiences and academic identity: The missing components of MOOC pedagogy. Journal of Online Learning and Teaching, 1O(1), 57-69.

Schmidt, J.P., Geith, C., Håklev, S., \& Thierstein, J. (2009). Peer-to-peer recognition of learning in open education. International Review of Research in Open and Distance Learning, 1O(5). Retrieved from http://www.irrodl.org/index.php/irrodl/article/viewFile/641/1392

Sledge. L., \& Dovey Fishman. T. (2014). Reimagining higher education. Westlake: Deloitte University Press.

Stacey, P. (2013, May 11). The pedagogy of MOOCs. Edtechfrontier.com. Retrieved from http://edtechfrontier.com/2013/05/11/the-pedagogy-of-moocs/

UNESCO. (2011). UNESCO ICT competencies framework for teachers. Paris: UNESCO.

Weller, M. (2011). A pedagogy of abundance. Spanish Journal of Pedagogy, 249, 223-236. Retrieved from http://oro.open.ac.uk/28774/2/BB62B2.pdf

Weller, M. (2012). The digital scholar. London: Bloomsbury Academic. Retrieved from https://www.bloomsburycollections.com/book/the-digital-scholar-how-technology-istransforming-scholarly-practice/ch1-digital-networked-and-open 
Weller, M. (2014). The battle for open. London: Ubiquity Press. Retrieved from http://www.ubiquitypress.com/site/books/detail/11/battle-for-open/

Wild, J. (2012). OER engagement study: Promoting OER reuse among academics. SCORE research report. Retrieved from https://ora.ox.ac.uk:443/objects/uuid:eca4f8cd-edf5-4b38-a9bo$4 \mathrm{dd} 2 \mathrm{~d} 4 \mathrm{e} 59750$

Wiley, D., \& Hilton, J. (2009). Openness, dynamic specialization, and the disaggregated future of higher education. International Review of Research in Open and Distance Learning, 1O(5). Retrieved from http://www.irrodl.org/index.php/irrodl/article/view/768/1414

\section{Athabasca \\ University}

(c) (i) 